\title{
STRATEGY BMT AL-ITTIHAD USING MATRIX IE, MATRIX SWOT 8K, MATRIX SPACE AND MATRIX TWOS
}

\author{
Nofrizal \\ Nofrizalfe@Unilak.ac.id \\ Lecturer Economic Faculty UniversityLancangKuningPekanbaru
}

\begin{abstract}
This research aims to formulate and select BMT Al-IttihadRumbai strategy to face the changing of business environment both from internalenvironment such as organization resources, finance, member and externalbusiness such as competitor, economy, politics and others. This research method used Analysis of EFAS, IFAS, IE Matrix, SWOT-8K Matrix, SPACE Matrix and TWOS Matrix. our hopefrom this research it can assist BMT Al-Ittihad in formulating and selecting strategies for the sustainability of BMT Al-Ittihad in the future. The sample in this research is using purposive sampling technique that is the manager and leader of BMT Al-IttihadRumbaiPekanbaru. The result of this research shows that the position of BMT Al-Ittihad using IE Matrix, SWOT-8K Matrix and SPACE Matrix is in growth position, stabilization and aggressive. The choice of strategy after using TWOS Matrix is market penetration, market development, vertical integration, horizontal integration, and stabilization (careful.)
\end{abstract}

Key Word: Strategic Management, Sharia Cooperative, TWOS Matrix 


\section{BACKGROUND}

Competition of cooperatives in the city of Pekanbaru increasingly more competitive with increase the development of an area where the cooperative was established.Pekanbaru city is a city whereas many high rise buildings have been established and will continue to grow. Pekanbaru City is also the best investment destination in Indonesia for investors of Sindo Weekly magazine (Antarariau, 2014). Currently the number of cooperatives active in the city of Pekanbaru amounted to 371 from the previous year only 300 with total cooperative 900 cooperatives (cooperatives and SMEs, 2014). This is certainly not separated from the role of government in the development of cooperatives in the city of Pekanbaru. Cooperatives and SMEs under the city government Pekanbaru has launched several policies to make cooperatives in the city of Pekanbaru develop and advance.

Cooperatives can'tseparated with the community where the cooperative was built because the community that will cooperate with each other to get what they want. By becoming members of the cooperative, each member of the cooperative has different behaviors such as wants fulfilled and needs then members of the cooperative will feel satisfied and trusty (Arizal N, Nofrizal, 2016)

BMT Al-IttihadRumbai is one of the non-bank financial institutions. BaitulMaalwaTamwil (BMT) as a mission-driven economic institution empowering small and small entrepreneurs applying sharia principles, it has been proven to play a role in building the economy of the people, especially the lower layers. With the increasing economic development in Pekanbaru city, today we can be seen with many emerging financial institutions that apply the principles of Islamic Sharia such as Syariah banking, Sharia Pawnshops, Sharia Insurance, Sharia co-operatives and BaitulMaalWatTamwil (BMT) in Pekanbaru city, it is causing every Sharia financial institution to be demanded to be more creative and innovative because of the increasingly competitive level of non-bank business to survive and beat the business competitors. 
With this condition, it will arisenews another non-bank financial institutions, so it will changes in consumer behavior as members of BMT Al-IttihadRumbai, so BMT can't just stand alone in the position. As we know BMT Al-Ittihad located close to the Chevron Fasifik Indonesia (CFI) complex of course full and voluntary members of BMT Al- Ittihad flat is the employee $(\mathrm{CFI})$ but in 2020 the exploitation contract in 2020 will be exhausted. Based on the circumstances it takes a formulation activity and strategy implementation for BMT Al-IttihadRumbai which started operations on 15 June 2000 and currently has three branches in Pekanbaru City can compete and survive with increasingly competitive competition..

According to Hunger and Wheelen (2012) strategic management is a series of decisions and managerial actions that determine the company's performance in the long run. These include environmental observations (external and internal), strategy formulation (long-term planning), strategy implementation, evaluation, and control. The field of strategic management science emphasizes the observation and evaluation of opportunities and threats of the environment by looking at the strengths and weaknesses of the company. Strategic management is in principle a decision-making that will determine whether an organization is superior, able to survive, or face death.

According Porter M (Fred R David, 2012) proposes a five-force model as a tool for analyzing an industry's competitive environment can be defined as a group of companies that produce the same product or service or close substitute. Internal factor evaluation will emphasize the identification and evaluation of strengths and weaknesses of firms in the business functional areas, including management, marketing, finance / accounting, production / operations, training and HR development, management information systems, and relationships between business areas. The strategic planner / development will be effective by using the SWOT analysis to achieve the organization's objectives. The SWOT has four factors namely the factors ofstrength, weakness, opportunities and 
threats (Mahima Gupta, Charu Shri Dr, Anshu Agrawal Dr, 2015) while the SWOT-8K Matrix is a development of the SWOT-4K Matrix.

The purpose of this Matrix IE, Matrix SPACE usage is to know how the position of strategy BMT AI-IttihadRumbiPekanbaru, the SPACE Matrix shows two internal provinces namely financial strength $(F S)$ and competitive advantage (CA) while in external factor also has two provinces namely environmental stabilization (ES) and Industrial Strength (IS). All these fakors are critical to achieving the goals of the company and the overall position of the company (Augustina and Kevin, 2013).

\section{RESEARCH METHODS}

Research using qualitative methods, According Sugiyono (2011) argued that the qualitative method of describing and understanding the meaning behind the data that looks. In this research to get information datawe use source from two type there are primary and secondary data. The research method used interview technique, questionnaire, observation and literature study. In this research, data analysis in the process with qualitative approach with the following stages: Vision and Mission Setting, IFAS Matrix (Internal Strategic Factors Analysis Summary) there is evaluation of strengths and weaknesses of firms in the business functional areas, including management, marketing, finance / accounting, production / operations, training and HR development, management information systems, and relationships between business areas. EFAS Matrix (External Strategic Factors Analysis Summary) there are two analysis the general environment and environmental industries. To determine the strategic position using IE Matrix, SWOT-8K Matrix and SPACE Matrix. As for the selection strategy using MatrixTWOS.

\section{RESULTS AND DISCUSSION}

\subsection{Results}

BMT Al-IttihadRumbai is the business development of the Islamic Education Unity Foundation (YKPI) Rumbai, by implementing the principle of Cooperation in accordance with Act No. 25 of 1992 on Cooperatives, 
but using the principle of Sharia Cooperative, started operations since June 15, 2000 with the name BaitulMaalWatTamwil Al-Ittihad, incorporated as of 31 January 2001 Number. 272 / BH / DISKOP \& UKM / 3 / X / 2001, Letter of Business License (SITU) number 517 / H / UPT / WK-2003, and BMT Optional Certificate number 034 / PINBUK / Riau / XI / 2000, addressed Cemara No. complex. 418, Camp PT. CPI, RumbaiPekanbaru.

The vision carried by BMT Al-Ittihad is "Become an integrated Islamic da'wah center to create a civil society that is prosperous born and inner and happy world and hereafter".

Mission "To encourage the creation of people in the field of Islamic muamalat business development".

After we look and analysis vision and mission BMT AlIttihadRumbai we sure that vision and mission was suitable with core business management to capture opportunity in Pekanbaru City. Next analyzing using general environmental analysis and industrial environment consisting of economic, social, politics, environment, technology, competitor, newcomer, buyer, supplier, product of substitute hence EFAS analysis of external environment BMT Al-IttihadRumbai found as in table 1 below. We found that BMT Al-Ittihad in good condition with positive value.

Table1. EFAS (External Environment) BMT Al-IttihadRumbai

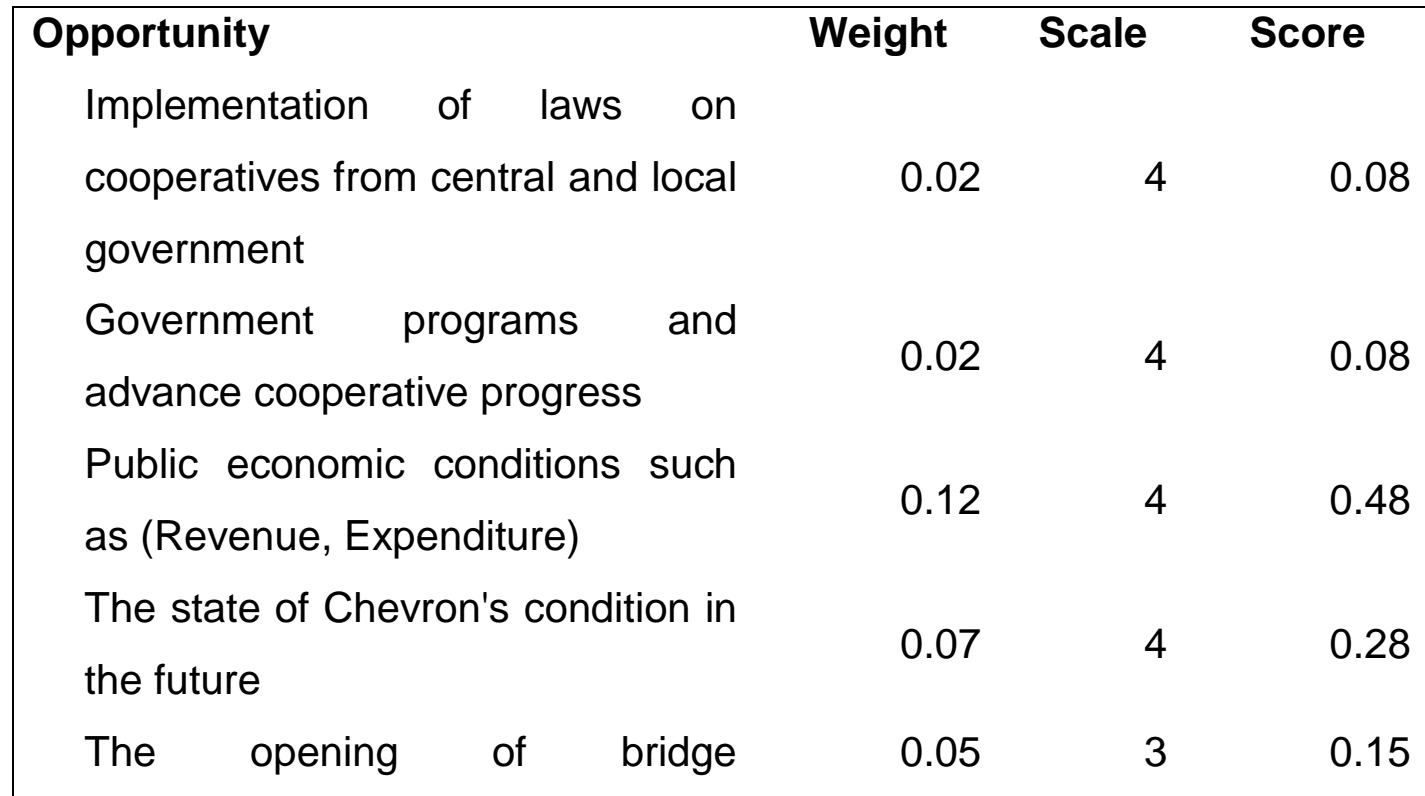


transportation access

The proliferation of continuous increases in the price of goods

(inflation)

Slow market growth

0.05

4

The number of people residing around BMT Al-Ittihad is a potential

$0.21 \quad 4$

market share

Population around BMT AlIttihadRumbai is Islamic

$0.09 \quad 4$

Technological advances (WA, Internet, Computers, etc.) are very rapid in an effort to improve business efficiency in the 0.12 4 environment BMT Al-Ittihad and society

\section{Threat}

Weight Scale Score

The amount of high competition between similar financial institutions and other conventional

$\begin{array}{lll}0.03 & 4 & 0.12\end{array}$
financial institutions

Easier institutions / individuals to open cooperatives

$\begin{array}{lll}0.04 & 3 & 0.12\end{array}$

There are many replacement products that people can choose when they want to use cooperative $\begin{array}{lll}0.05 & 4 & 0.20\end{array}$ services

The buyer's bargaining power has a major influence on the operation of BMT Al-IttihadRumbai

There are many suppliers to support / support the business 
operations of BMT Al-Ittihad

Total

Source: (Data process, 2018)

Based on table 1 above about the analysis of the external environment BMT Al-IttihadRumbai city Pekanbaruwe know that BMT Al-Ittihad condition was positioned positively with the value 3.91 , then from the value of opportunities found the factors of technological progress and economic circumstances that the community's income in good condition with score 0.48, this shows that BMT Al-IttihadRumbai has a great opportunity to capture the cooperative market opportunities in Pekanbaru City with this condition is also of course BMT Al-Ittihad to advance and grow also larger.

While on the threat factor is known value that has a big influence on the future of BMT Al-IttihadRumbai is the amount of high competition between similar financial institutions, Easy to open cooperatives and there are many products replacement, with this condition BMT Al-Ittihad will not be easy to go forward and compete, but this threat can be over by harnessing the power still held to be discussed in the IFAS 2 next table.

Table 2.IFAS (Internal Environment) BMT Al-IttihadRumbai

\section{Strength}

Weight Scale Score

Qualified human resources

$0.05 \quad 4 \quad 0.20$

There are skills development and motivation

programs for employees

$\begin{array}{lll}0.01 & 3 & 0.03\end{array}$

Have career development programs for

employees

$0.11 \quad 3 \quad 0.33$

Having SOP (Standard Operating Procedure)

in running the business

$0.07 \quad 3 \quad 0.21$

There are rewards and punishments for outstanding employees and mistakes

$\begin{array}{lll}0.05 & 3 & 0.15\end{array}$

The current financial condition of BMT Al-

$\begin{array}{lll}0.08 & 3 & 0.24\end{array}$




\begin{tabular}{|c|c|c|c|}
\hline \multicolumn{4}{|l|}{ Ittihad } \\
\hline Amount of Debt with ability to repay debt & 0.05 & 3 & 0.15 \\
\hline $\begin{array}{l}\text { Have other business units to support BMT Al- } \\
\text { Ittihad business other than cooperatives }\end{array}$ & 0.09 & 1 & 0.09 \\
\hline $\begin{array}{l}\text { Have innovative products offered to the public } \\
\text { / customers }\end{array}$ & 0.09 & 3 & 0.27 \\
\hline $\begin{array}{l}\text { Has a wide market segmentation for BMT Al- } \\
\text { Ittihad products }\end{array}$ & 0.08 & 4 & 0.32 \\
\hline $\begin{array}{l}\text { It has facilities and several branches for easy } \\
\text { reach by the community / customers }\end{array}$ & 0.03 & 3 & 0.09 \\
\hline BMT Al-Ittihad already known by the public & 0.04 & 3 & 0.12 \\
\hline $\begin{array}{l}\text { Ease of requirement to become a new } \\
\text { member }\end{array}$ & 0.05 & 4 & 0.20 \\
\hline Weakness & Weight & Scale & Score \\
\hline $\begin{array}{l}\text { The service capabilities of BMT AI- } \\
\text { IttihadRumbai employees }\end{array}$ & 0.01 & 3 & 0.03 \\
\hline $\begin{array}{l}\text { The state of communication between } \\
\text { employees and between leaders and } \\
\text { employees }\end{array}$ & 0.03 & 3 & 0.09 \\
\hline Employee wellbeing so far & 0.05 & 3 & 0.15 \\
\hline $\begin{array}{l}\text { Relationship between management and } \\
\text { employees }\end{array}$ & 0.03 & 3 & 0.09 \\
\hline Implementation of SOP (Standard Operating & & & \\
\hline $\begin{array}{l}\text { Procedure) which has been made by the } \\
\text { management }\end{array}$ & 0.03 & 3 & 0.09 \\
\hline $\begin{array}{l}\text { The physical condition (Building) BMT AI- } \\
\text { Ittihad }\end{array}$ & 0.02 & 3 & 0.06 \\
\hline Not so much promoting new customers & 0.01 & 3 & 0.03 \\
\hline $\begin{array}{l}\text { effective promotion through advertisements } \\
\text { and newspapers }\end{array}$ & 0.01 & 3 & 0.03 \\
\hline $\begin{array}{l}\text { Have a programmed and programmed } \\
\text { marketing strategy }\end{array}$ & 0.01 & 3 & 0.03 \\
\hline
\end{tabular}




\begin{tabular}{|lll|}
\hline Total & 1 & 3.00 \\
\hline
\end{tabular}

Source: (Data process, 2018)

Based on table 2 above obtained internal calculation results BMT AIIttihadRumbai show the same positive with the results obtained in the previous EFAS table. From the power factor, it know that the strongest strength factor is to have a career development program for employees, BMT Al-Ittihad's current financial condition and has wide market segmentation for BMT Al-lttihad products. While on the weakness factor there are some that have a big effect on BMT Al-Ittihad is the welfare of employees over the years and Implementation of SOP (Standard Operational Procedures) that have been made by the management. Based on these factors then the total score score of BMT Al-IttihadRumbai is 3.00 this means the condition of BMT at this time remain in good condition but must keep improving on the weakness. In addition, some of the weaknesses of the piles of many human resource problems $(H R)$. Therefore, this problem can be solved in many ways such as training, reward and punishment or can also improve the system of recruitment of employee to get reliable manpower.

From the calculation table IFAS and EFAS obtained EFAS value of 3.91 and score for IFAS results of 3.00. When converted into the IE Matrix Diagram, then it is located in boxes 1 and 5, where the results of the firm enter into the Growth and Stability phases see table 3 below

Table 3.Matrix IE BMT Al-IttihadRumbai

\begin{tabular}{c|c|c|c|}
\multicolumn{1}{c}{} & $\begin{array}{c}\text { Strong } \\
(3.0-4.0)\end{array}$ & Medium(0.2-2.99) & \multicolumn{2}{c}{$\begin{array}{c}\text { Low } \\
(\mathbf{0 . 1 - 1 . 9 9 )}\end{array}$} \\
\cline { 2 - 4 } $\begin{array}{c}\text { Strong } \\
(3.0-4.0)\end{array}$ & $\begin{array}{c}\text { 1. Growth } \\
\text { Concentration } \\
\text { Through Vertical } \\
\text { Integration }\end{array}$ & $\begin{array}{c}\text { 2. Growth } \\
\text { Concentration } \\
\text { Through Horizontal } \\
\text { Integration }\end{array}$ & $\begin{array}{c}\text { 4. Retrenchment } \\
\text { Restructuring }\end{array}$ \\
\hline
\end{tabular}




\begin{tabular}{|c|c|c|c|}
\hline $\begin{array}{l}\text { Medium } \\
(0.2-2.99)\end{array}$ & $\begin{array}{l}\text { 5. Stability } \\
\text { Watch Out }\end{array}$ & \begin{tabular}{|c|} 
5. Growth \\
Concentration \\
Through Horizontal \\
Stability Integration \\
No change in \\
strategy profit
\end{tabular} & $\begin{array}{l}\text { 6. Retrenchment } \\
\text { Partial Closure } \\
\text { business }\end{array}$ \\
\hline $\begin{array}{c}\text { Low } \\
(0.1-1.99)\end{array}$ & $\begin{array}{c}\text { 7.Growth } \\
\text { Concentric } \\
\text { Diversification }\end{array}$ & $\begin{array}{c}\text { 8. Growth } \\
\text { Diversified } \\
\text { Conglomerate }\end{array}$ & $\begin{array}{l}\text { 8. Retrenchment } \\
\text { Bankrupt } \\
\text { or } \\
\text { Liquidation }\end{array}$ \\
\hline
\end{tabular}

Source: (Data Process, 2018)

Based on the IE Matrix image above the strategy that can be used is growth (growth) through vertical integration of construction this means BMT Al-Ittihad can use growth strategy Integration strategy is a strategy to seek ownership or improve control of company suppliers. The strategy is particularly appropriate when the company's suppliers are not reliable, overpriced, or do not meet the needs of the company or seek ownership of the distribution of products to customers by acquiring product distribution.

Besides using IE Matrix, this research also uses SWOT 8K Matrix. This matrix has eight (sub) quadrants. The SWOT-8K matrix is useful for formulating corporate planning because this matrix will show what strategy is appropriate to use. This matrix is derived from the difference between EFAS and IFAS values. The result of calculating the value of the difference of opportunity and the threat from external factor is the value of 2.71. While the difference between strength and weakness of internal factors

with value 1.80. Based on these results it can be concluded that the position of BMT strategy Al-IttihadRumbai is in the Stable Growth Strategy (stable Growth Strategy) or in the quadrant IA as in Figure 2 below 
Figure 2.Matrix SWOT 8K BMT Al-IttihadRumbai

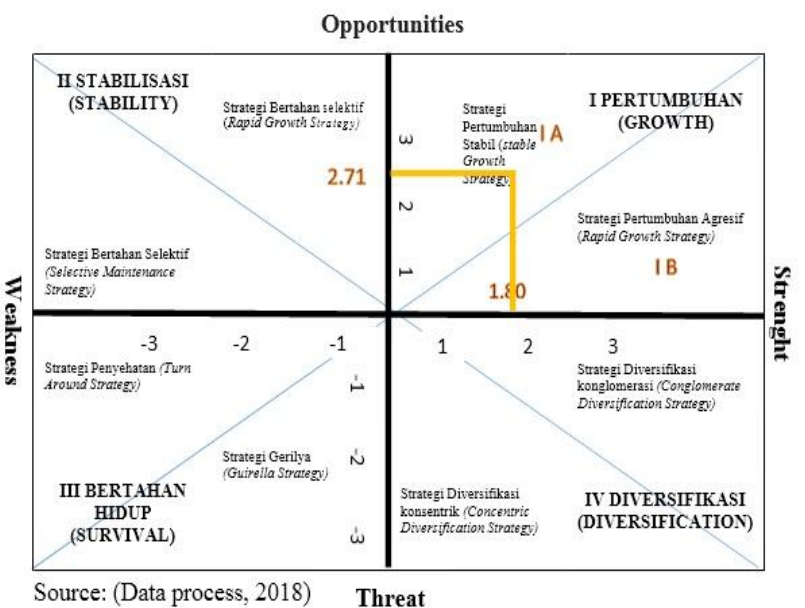

Based on the above picture 2 it can be retrieved that the right strategy that can be done by BMT Al-Ittihad is a Growth Stable Strategy (stable Growth Strategy). This strategy means that this strategy is usually done by companies that have many power items, while they are in an industry with high attractiveness. Simply put, the company is having the strength or ability to expand, because of its attractive external conditions, and favorable internal conditions. Ability here could be in the form of financial resources (can be own funds or funds from third parties), or resources of any kind. As a business organization, instinct to always growis always there. There are two strategies for growth that is (concentration) and Diversification (diversification).

Next use the SPACE Matrix consisting of a four-quadrant framework consisting of aggressive, conservative, defensive, and comprehensive strategies, in which these four quadrants indicate which strategy best fits a particular organization. The SPACE Matrix Axis depicts two internal dimensions and two external dimensions. Two internal dimensions include strength (financial strength $=F S$ ) and competitive advantage (CA). Results after using the SPACE Matrix by observing the four demands and distributing questionnaires to BMT Al-Ittihad it was found that the position of BMT Al-IttihadRumbai was in the Aggressive position with the total value of horizontal axis 1.75 while the vertical axis 1.70 such as Table 5.6 and Figure 5.6 
Table 4.Matrix Space BMT Al-IttihadRumbai

\begin{tabular}{|c|c|c|c|}
\hline Financial Strength (FS) & $\begin{array}{l}\text { Rat } \\
\text { ing }\end{array}$ & $\begin{array}{c}\text { Environmental Stability } \\
\text { (ES) }\end{array}$ & $\begin{array}{l}\text { Rat } \\
\text { ing }\end{array}$ \\
\hline a. ROI & 3 & $\begin{array}{l}\text { a. } \\
\text { echnology changes }\end{array}$ & -3 \\
\hline b. Leverage & 3 & $\begin{array}{l}\text { b. } \\
\text { ompetition Pressure }\end{array}$ & -2 \\
\hline c. Liquidity & 4 & $\begin{array}{l}\text { C. } \\
\text { emand Diversity }\end{array}$ & -1 \\
\hline \multirow[t]{2}{*}{ d. Working capital } & 4 & $\begin{array}{l}\text { d. } \\
\text { rice competition }\end{array}$ & -1 \\
\hline & & $\begin{array}{l}\text { e. } \\
\text { nflation Rate }\end{array}$ & -2 \\
\hline $14 / 4$ & $\begin{array}{r}3.5 \\
0\end{array}$ & $9 / 5$ & -1.8 \\
\hline $\begin{array}{c}\text { Competitive Advantages } \\
\text { (CA) }\end{array}$ & $\begin{array}{l}\text { Rat } \\
\text { ing }\end{array}$ & Industrial Strength (IS) & $\begin{array}{l}\text { Rat } \\
\text { ing }\end{array}$ \\
\hline $\begin{array}{l}\text { a. } \\
\text { arket share }\end{array}$ & -1 & $\begin{array}{l}\text { a. } \\
\text { rowth Potential }\end{array}$ & 3 \\
\hline $\begin{array}{l}\text { b. } \\
\text { uality Products and awards }\end{array}$ & -2 & b. Resource Utilization & 3 \\
\hline $\begin{array}{l}\text { C. } \\
\text { ustomer loyalty }\end{array}$ & -1 & c.Ease of Entry into Industry & 3 \\
\hline $\begin{array}{l}\text { d. } \\
\text { nowledge of technology }\end{array}$ & -2 & d. Productivity & 4 \\
\hline $6 / 4$ & -1.5 & & $\begin{array}{r}3.2 \\
5\end{array}$ \\
\hline & & Total Axis Horizontal & $\begin{array}{r}1.7 \\
5\end{array}$ \\
\hline & & Total Axis Vertical & $\begin{array}{r}1.7 \\
0\end{array}$ \\
\hline
\end{tabular}


Source: (Data Process, 2018)

Based on the above table it is known that the state of BMT AlIttihadRumbai in the state of aggressive strategy see figure 3 below, the strategy has meaning means the company is in a good position to use its internal strength to take advantage of external opportunities, overcome internal weaknesses, and avoid external threats. Thus, market penetration, market development, product development, backward integration, forward integration, horizontal integration and conglomerate diversification (concentric diversification, horizontal diversification can be one effective strategy that can be used by BMT Al-IttihadRumbai.

Figure 3.Matrix SPACE BMT Al-IttihadRumbai

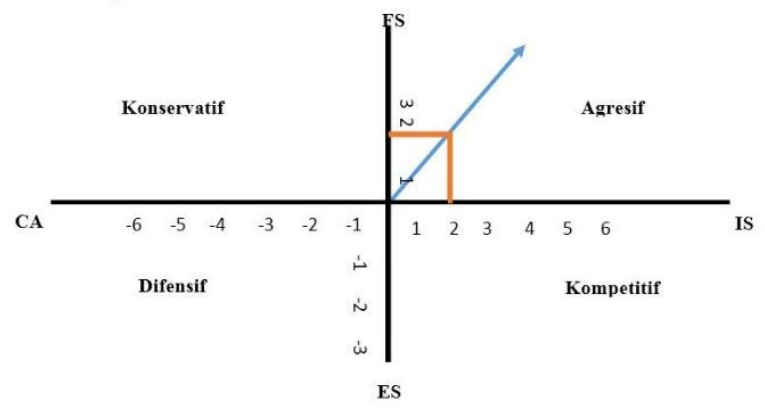

The last stage in BMT Al-IttihadRumbai strategy development is the selection of strategy using TWOS matrix see table 6 after considering EFAS Matrix, IFAS Matrix, IE Matrix, SWOT 8K Matrix and SPACE Matrix. Based on the TOWS Matrix then BMT Al-IttihadRumbai can choose and use some formulation of strategy to run the cooperative in the future that is as follows:

1. Maximize the 4 branches that are owned now by providing maximum service to customers.

2. Creating attractive programs to new and old prospective customers such as products for children's education, umrah and haji

3. Maximize the program for human resource development to improve HR performance. 
4. Create a growth strategy by opening a business unit that is related to a business unit or unrelated to a business unit

5. Partnering with SMEs and SMEs in the city of Pekanbaru.

6. Create ainterestingcampaign to prospective new customers and old customers by way of computing between the cooperative industry in the city of Pekanbaru such as promotion of interest credit and ease of lending.

7. Provide an understanding to the employee that our cooperative is the best cooperative in Pekanbaru city with a series of award.

\section{Discussion}

BMT Al-IttihadRumbaiis a business unit that moves to save and borrow with the concept of cooperative sharia. With the advancement of the region and the increasing number of people increasing the day it becomes an opportunity for entrepreneurs or investors as well as to capture economic opportunities to generate profits. Cooperatives as a means of financing that have mutual cooperationattitude also appear including BMT Al-lttihad as a cooperative sharia. With the increasing number of emerging cooperatives and financial institutions, competition is inevitable for it needed a strategy in order to compete and survive in the future.

The result of this research shows that BMT Al-Ittihad fringe is in good position this is indicated by 3 matrix that is IE matrix, SWOT $8 \mathrm{~K}$ matrix and SPACE Matrix like table 5 below. 
Table 5.BMT Al-Ittihad strategic position using IE Matrix, SWOT 8K Matrix, SPACE Matrix

\begin{tabular}{|c|c|c|}
\hline Matrix IE & $\begin{array}{c}\text { Matrix } \\
\text { SWOT 8K }\end{array}$ & $\begin{array}{c}\text { Matrix } \\
\text { SPACE }\end{array}$ \\
\hline Growth & Growth \& & Aggressive \\
Strategy & Stable & Strategy \\
Vertical & Strategy & \\
Concentration & (stable & \\
& Growth & \\
& Strategy & \\
& & \\
& & \\
\end{tabular}

Based on the picture above can be concluded that BMT Al-IttihadRumbai strategy is in a healthy position. Under these circumstances, BMT AlIttihad can do many things for future strategies such as market penetration, market development, product development, backward integration, forward integration (a strategy implemented by gaining control over the distribution channels, from distributors to retailers ), horizontal integration and diversification of conglomerates.

The above strategies can be formulated into the TWOS matrix including maximizing the 4 branches that are owned now by providing maximum service to the customer in accordance with the opinion of (DonyWaluyaFirdaus, 2013) with the title of research to build and implement balanced scorecard on public sector, attractive programs to new and old prospective customers such as products for children's education, umrah and hajj and maximizingprogram for human resource developers to improve HR performance.

As for the reason why BMT Al-IttihadRumbai should focus on maximizing 4 branches and improving the ability of employees this is in accordance with the revelation (Supriyadi, 2017) that the results show that the motivation and managerial effect on employee performance because of financial ability is quite good plus the number of customers the many as 
well as the esteem-pricing from the government or institution that can be a good image. The best way to convey this is to use the marketing strategy in accordance with the opinion (Saputro, Hidayat and Yulianto, 2016) that the results of the research show the appropriate strategy for PT. Telkomsel Branch Malang is an intensive strategy consisting of market penetration, market development, and product development

\section{CONCLUSIONS AND RECOMMENDATIONS}

From the result of this research, it can be concluded that BMT AlIttihad as sharia cooperative has strategy formulation BMT AlIttihadRumbai can use growth strategy, aggressive and stabilitywhile position of BMT strategy Al-lttihadRumbaiis in good position because it is in positive quadrant that is aggressive, growth, and stabilization while from the three matrix IE matrix matrix SWOT 8K and matrix SPACE matrix all show good performance which is suggested to use growth strategy and stabilization after known from TWOS matrix analysis to formulate strategy found some strategy that can be selected BMT Al- Ittihad among them maximize4 branches that already exist that is branches.Rumbai branches.Panam and branches.Duri, open cooperation with SMEs and SMEs, maximize the performance of the customers by creating programs opening business units, conducting programs or promotional products related to Islamic religious values.

While the advice of BMT Al-IttihadRumbai is BMT Al-IttihadRumbai should be able to analyze the external and internal environment because this environment is very fast changing and sometimes not terpredeksi by the management then create a list of especiallylist for top leaders and managers, BMT Al-lttihad maximizing the advantages possessed now as a positive image both government and private and customers, BMT AlIttihad can use social media as a product promotion tool to potential customers or existing customers, BMT Al-lttihad can use existing finance by making diversified products to society in accordance with the needs of today's society and religious programs quite often done in the city of 
Nofrizal_Strategy BMT Al-Ittihad Using Matrix IE, Matrix SWOT 8K, Matrix Space And Matrix Twos

Pekanbaru is a good opportunity for BMT Al-Ittihad to serve as a sponsor to introduce products BMT to the city of Pekanbaru. 
Table 6. Matrix TWOS BMT Al-lttihadRumbai

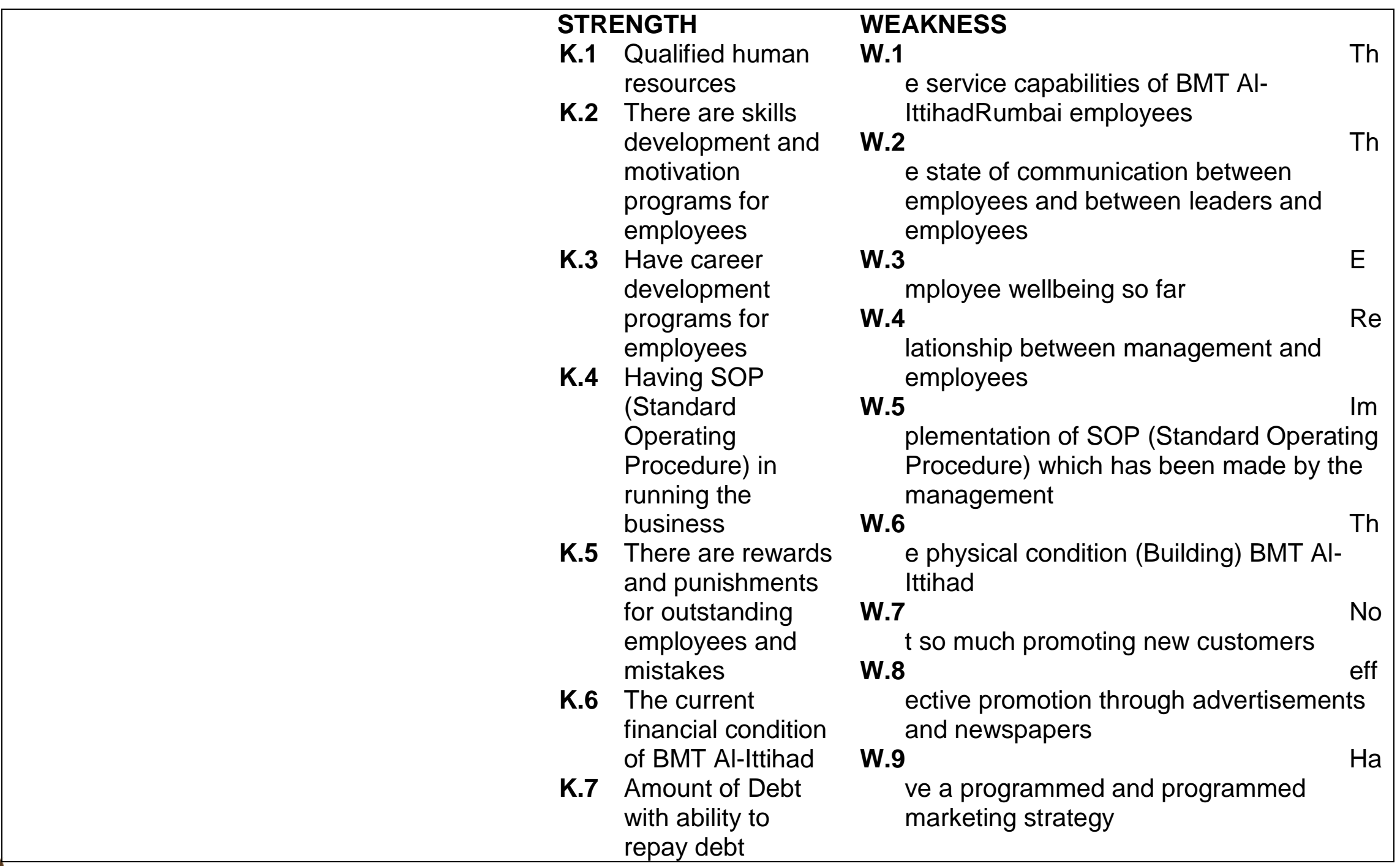




\begin{tabular}{|c|c|c|}
\hline & $\begin{array}{l}\text { K.8 } \begin{array}{l}\text { Have other } \\
\text { business units to } \\
\text { support BMT Al- } \\
\text { Ittihad business } \\
\text { other than } \\
\text { cooperatives } \\
\text { K.9 } \begin{array}{l}\text { Have innovative } \\
\text { products offered } \\
\text { to the public / } \\
\text { customers }\end{array} \\
\text { K.10 } \begin{array}{l}\text { Has a wide market } \\
\text { segmentation for }\end{array} \\
\text { BMT Al-lttihad } \\
\text { products } \\
\text { K.11 It has facilities and } \\
\text { several branches } \\
\text { for easy reach by } \\
\text { the community / } \\
\text { customers } \\
\text { K.12 } \begin{array}{l}\text { BMT Al-lttihad } \\
\text { already known by } \\
\text { the public }\end{array} \\
\text { K.13 Ease of } \\
\text { requirement to } \\
\text { become a new } \\
\text { member }\end{array} \\
\end{array}$ & \\
\hline $\begin{array}{l}\text { OPPORTUNITY } \\
\text { P.1 Im } \\
\text { plementation of laws on cooperatives from } \\
\text { central and local government. }\end{array}$ & $\begin{array}{l}\text { SO STRATEGI } \\
\text { 1. Maximize the } 4 \\
\text { branches that are } \\
\text { owned now by }\end{array}$ & $\begin{array}{l}\text { WO STRATEGY } \\
\text { Provide motivation to employees both } \\
\text { morally and materially as well as provide } \\
\text { opportunities for employees to grow }\end{array}$ \\
\hline
\end{tabular}




\begin{tabular}{|c|c|c|c|}
\hline $\begin{array}{l}\text { e state of Chevron's condition in the futur } \\
\text { P.5 } \\
\text { e opening of bridge transportation access } \\
\text { P.6 } \\
\text { e proliferation of continuous increases in } \\
\text { the price of goods (inflation). } \\
\text { P.7 } \\
\text { ow market growth } \\
\text { P.8 } \\
\text { e number of people residing around BMT } \\
\text { Al-Ittihad is a potential market share. } \\
\text { P.9 } \\
\text { pulation around BMT Al-IttihadRumbai is } \\
\text { Islamic } \\
\text { P.10 } \\
\text { chnological advances (WA, Internet, } \\
\text { Computers, etc.) are very rapid in an effo } \\
\text { to improve business efficiency in the } \\
\text { environment BMT Al-Ittihad and society }\end{array}$ & 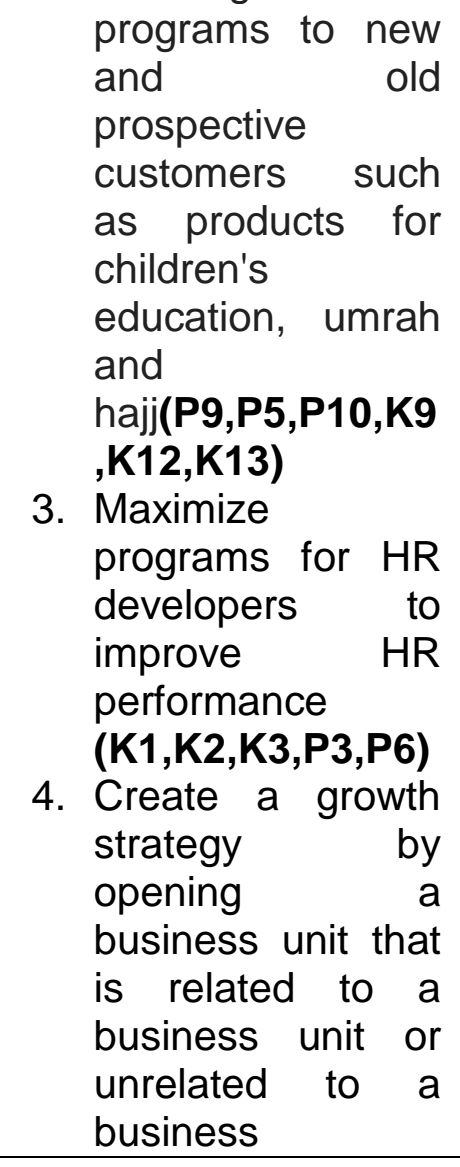 & 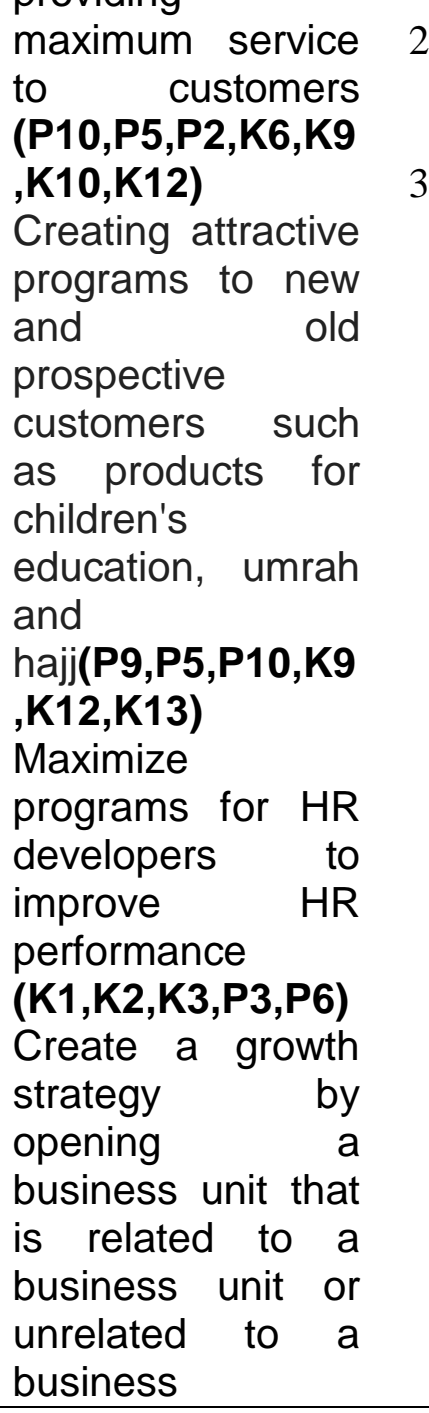 & $\begin{array}{l}\text { 2. Make interesting promotional strategies } \\
\text { by creating events like religious events } \\
\text { (P3,P4,W8,W9,W7) } \\
\text { activities between the leadership and } \\
\text { subordinates (W4, P10) } \\
\text {. }\end{array}$ \\
\hline
\end{tabular}




\begin{tabular}{|c|c|c|}
\hline & $\begin{array}{l}\text { unit(K6,K10,K12, } \\
\text { P4) } \\
\text { 5. Partnering with } \\
\text { SMEs and SMEs } \\
\text { in Pekanbaru city } \\
\text { (P10,P3,P7,K6,K1 } \\
\text { 0) }\end{array}$ & \\
\hline $\begin{array}{l}\text { THREAT } \\
\text { A.1 } \\
\text { e amount of high competition between } \\
\text { similar financial institutions and other } \\
\text { conventional financial institutions } \\
\text { A.2 } \\
\text { sier institutions / individuals to open } \\
\text { cooperatives } \\
\text { A. } 3 \text { Ea } \\
\text { ere are many replacement products that } \\
\text { people can choose when they want to use } \\
\text { cooperative services } \\
\text { A.4 Th } \\
\text { e buyer's bargaining power has a major } \\
\text { influence on the operation of BMT Al- } \\
\text { IttihadRumbai } \\
\text { A.5 ere are many suppliers to support / support } \\
\text { the business operations of BMT Al-Ittihad }\end{array}$ & $\begin{array}{l}\text { ST STRATEGY } \\
\text { 1. Creating an } \\
\text { attractive } \\
\text { promotion to } \\
\text { prospective new } \\
\text { customers and old } \\
\text { customers by way } \\
\text { of computing } \\
\text { between the } \\
\text { cooperative city } \\
\text { industry in the city } \\
\text { of Pekanbaru } \\
\text { such as the } \\
\text { promotion of } \\
\text { interest credit and } \\
\text { ease of lending } \\
\text { (A1,A2,K6,K7,K1 } \\
\text { 0,K9) best } \\
\text { 2. } \text { Provide to } \\
\text { understanding to } \\
\text { employees that } \\
\text { our cooperative is } \\
\text { the be best }\end{array}$ & $\begin{array}{l}\text { WT STRATEGI } \\
\text { 1. There should be special attention to the } \\
\text { facilities owned by BMT Al-lttihad at this } \\
\text { time }(\mathbf{A} 1, \mathbf{A} 2, \mathbf{A} 3, \mathbf{W} 6) \\
\text { 2. Making a comparative study to banks } \\
\text { further applies it to BMT Al-lttihad to } \\
\text { improve customer service }(\mathbf{A} 1, \mathbf{A} 2, \mathbf{A} 3)\end{array}$ \\
\hline
\end{tabular}




\section{Nofrizal_Strategy BMT Al-Ittihad Using Matrix IE, Matrix SWOT 8K, Matrix Space And Matrix Twos}

\begin{tabular}{|l|}
\hline cooperative in \\
Pekanbaru city \\
with a series of \\
achievements and \\
awards \\
(A3,K1,K2,K3) \\
\hline
\end{tabular}




\section{REFERENCES}

AugustinaAsihRumanti and Kevin Joseph Syauta, 2013, Determining Strategies Based on Strategic Position Analysis in Small and Medium Enterprises, International Journal of Information and Education Technology, Vol. 3, No. 4, August 2013, Hal 443-447 BayuAgustariAdha, 2014, PekanbaruMenggeliatMenuju Kota Metropolitan

Yang Madani, Di Akses 31 Agustus 2016, Dari http://www.antarariau.com/berita/36144 /pekanbaru-menggeliatmenuju-kota- metropolitan-yang-madani

David Fred. R, 2010, ManajemenStrategikKonsep. Jakarta: SalembaEmpat

David Fred. R, 2012, ManajemenStrategikKonsep. Jakarta: SalembaEmpat

DonyWaluyaFirdaus (2013) 'MembangundanImplementasi Balanced Scorecard padaSektorPublik', Majalahllmiah UNIKOM, 9.No.1(2), pp. 3-10.

Edwin hartono, 2013,

PengelolaandanPengembanganBisnisJasaKebugaranPada

Artharaga Fitness Center, Jurnal Agora, vol.1, no.3 Februari 2013, 80-89 Hermawan, 2013, PekanbaruPotensialJadiPusatEkonomi Sumatera, di akses 31

Agustus 2016, dari http://riaupos.co/27011-arsip-hermawanpekanbarupotensial-jadi-pusat-ekonomisumatera.html\#.V8bQQ1t944x

Gomatesh M. RavanavarAndPoornima M. Charantimath, 2012, Strategic Formulation Using Tows Matrix - A Case Study, International Journal Of Research And Development, Volume 1, Issue 1

Mahima Gupta, Charu Shri Dr, Anshu Agrawal Dr, 2015, Strategy Formulation for Performance Improvement of Indian Corrugated Industry: An Application of SWOT Analysis and QSPM Matrix, Journal of Applied Packaging Research: Vol. 7: No. 3, Hal 60-75 
Nofrizal, 2015, EvaluasiStrategi Spartan Gym

DenganMenggunakanMetodeBalanced Scorecard, JurnalDayaSaing, Vol. 2, No. 2 Juni 2016, 50-59

Wheelen, dan Hunger, 2012. Strategic Management and Business Policy, Ed. 9, Prentice Hall.

Said Elbanna, 2010, Strategic planning in the United Arab Emirates, InternationalJournal of Commerce and Management, Vol. 20 No. 1, 2010 hal. $26-40$

Saputro, A. S., Hidayat, K. AndYulianto, E. (2016)

'PerencanaanStrategiPemasaranPaket Data

KampusDalamPersaingan Di BidangPaket Data Internet (StudiKasuspada PT. TelkomselCabang Malang)', JurnalAdministrasiBisnis, 36(1), pp. 163-169.

Swarsono Muhammad, 2008. Matriks\&SkenariodalamStrategi,

Yogyakarta: UPP STIM YKPN

Sugiyono, 2010, Statistikauntukpenelitian, Bandung, Alphabets

Supriyadi, D. (2017) 'PengaruhMotivasi Dan

ManajerialTerhadapKinerjaKaryawan Bank', Value Journal Of Management And Business, 1(2), Pp. 139-148. Thompson, A. A.,

Strickland III, A. J. and Gamble, J. E. 2010. Crafting and Executing Strategy: The Quest For Competitive Advantage: Concepts and Case. Seventeenth Edition. McGraw-Hill

Robert G. Dyson, 2002, Strategic development and SWOT analysis at the University of Warwick, European Journal of Operational Research, 152 (2004), hal 631-640 